DE GRUYTER GOSPODARKA SUROWCAMI MINERALNYMI - MINERAL RESOURCES MANAGEMENT

\title{
Gold deposits of the Czech Republic from a mineral policy perspective
}

\section{Introduction}

Gold deposits have been intermittently exploited in the territory that forms the presentday Czech Republic for more than three-thousand years. The last gold ore was exhausted in 1994 during liquidation work at the Zlaté Hory deposit (Zelinger ed. 1998). Gold deposits have not been exploited in the Czech Republic since that time, even though 15 deposits with a total of nearly 239 tonnes of geological resources of gold are listed in the Register of Reserved Mineral Reserves of the Czech Republic. At least three of the deposits, Mokrsko with 98 tonnes of gold resources (with its eastern part having more than 118 tonnes of gold), Kašperské Hory with 55 tonnes of gold (115 tonnes including prognosticated resources) and Vacíkov with more than 33 tonnes of gold, may be regarded as relatively significant medium-sized deposits (Starý et al. eds. 2013). None of these deposits are currently mined, and

* Ing., **** Mgr., Raw Materials and Energy Security Division, Ministry of Industry and Trade of the Czech Republic, Praha, Czech Republic.

** RNDr., Czech Geological Survey, Praha, Czech Republic.

*** Ing., Czech Mining Authority, Department for Moravian-Silesian and Olomouc Regions, Ostrava, Czech Republic.

***** Ing., Ph.D., Insitute of Geological Engineering, Faculty of Mining and Geology, Vysoká škola báňská Technical University of Ostrava, Ostrava-Poruba, Czech Republic, e-mail: jakub.jirasek@vsb.cz

****** Prof. Ing., CSc., Insitute of Geological Engineering, Faculty of Mining and Geology, Vysoká škola báňská - Technical University of Ostrava, Ostrava-Poruba, Czech Republic. 
their potential future exploitation still remains in question. The following text describes the current stance on the above-mentioned issue in terms of the legislative and mineral policy of the Czech Republic, including the history of gold production in its territory.

\section{History of gold mining in the Czech Republic region}

Gold deposits occur in the territory that makes up the Czech Republic (hereinafter referred to as the "CR") in a region formed by the Bohemian Massif (Cháb ed. 2010). Secondary (placer) as well as primary (hydrothermal, volcano-sedimentary-hosted and porphyry) deposits are present. The classification of these deposits according to industrial type was introduced by Morávek (Morávek ed. 1992). Gold deposits have been exploited in the region of the present-day CR for more than three-thousand years. This period is usually divided into four eras, which are characterized by different technologies used to exploit deposits and also by the deposit type mined.

The most significant periods of gold production in the $\mathrm{CR}$ region are considered to be the era of Celtic settlement (the 6th century before the Common Era to the turn of the Common Era), with an estimated production of approximately 40 tonnes of gold, and from the 12th to the 14th century of the Common Era, with a production of approximately 48 tonnes of gold. An estimated 9 tonnes of gold, predominantly from deposits already known, were produced in the 20th century. However, only the output of the Roudný deposit was of real economic

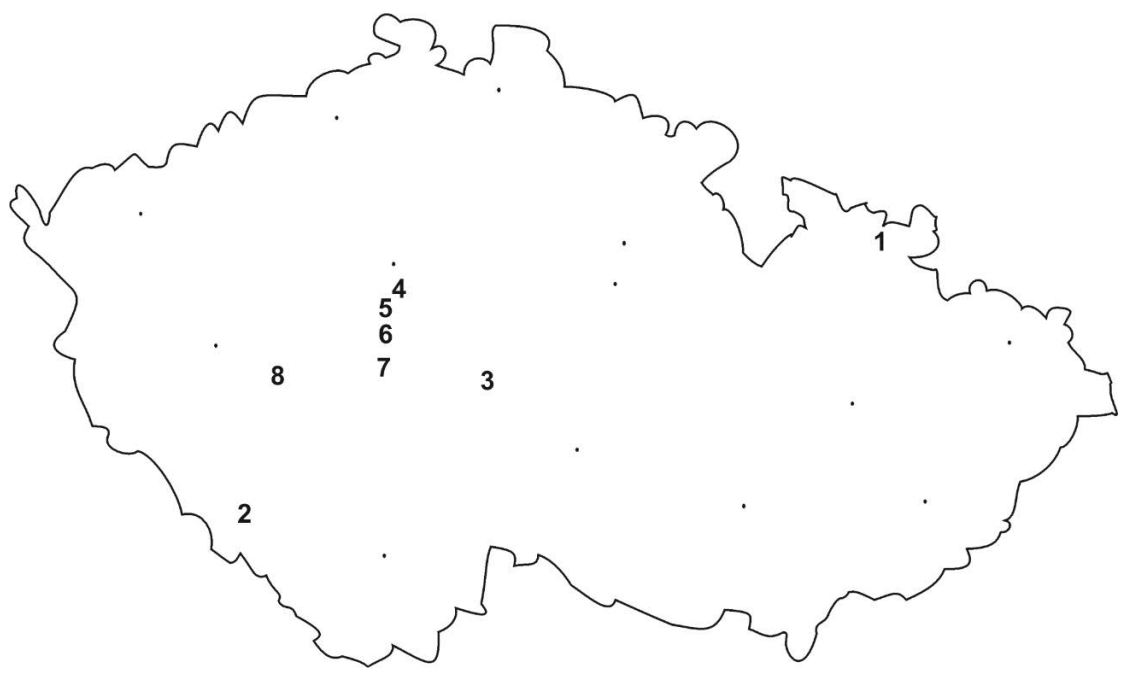

Fig. 1. The most important gold deposits in the Czech Republic region 1 - Zlaté Hory + Suchá Rudná, 2 - Kašperské Hory, 3 - Roudný, 4 - Jílové u Prahy, 5 - Nový Knín + Libčice + Mokrsko + Čelina, 6- Krásná Hora, 7 - Voltýřov, 8 - Vacíkov

Rys. 1. Najważniejsze złoża złota w Republice Czeskiej

1 - Zlaté Hory + Suchá Rudná, 2 - Kašperské Hory, 3 - Roudný, 4 - Jílové u Prahy, 5 - Nový Knín + Libčice + Mokrsko + Čelina, 6- Krásná Hora, 7 - Voltýřov, 8 - Vacíkov 
importance. The entire historical gold production in the CR region over a time period of more than two thousand years is generally estimated at nearly 100 tonnes (for example, Morávek ed. 1992). The location of the deposits mentioned later in the text are shown in Figure 1.

\subsection{From the earliest times to the 16 th century}

The oldest archeologically documented placer gold mining in our territory dates back to approximately 1500 BCE in Suchá Rudná in the Jeseník Mts. and, in the 9th century BCE, in the Otava River in Modlešovice near Strakonice. Sometime in the middle of the first millennium BCE, gold that came predominantly from placers in the river basins of the Otava, Vltava and Opava began to be processed. The total gold production during the earliest period of our history may have reached approximately 40 tonnes (Morávek 1980; Morávek ed. 1992).

In the 13th and 14th centuries, Bohemia was one of the main regions of gold production in Europe. The ongoing placer gold mining at many localities exhausted the majority of previously high-grade deposits by the end of the 13th century. This was an impulse to switch to underground mining of primary deposits. The largest mining operations at that time are known to have been in Jílové u Prahy and Kašperské Hory. The total gold production of the Jílové mining district in the 13th and 14th centuries is estimated at 6-10 tonnes (approximately $65-90 \mathrm{~kg}$ annually). The production declined gradually in the second half of the 14th century, and its end was caused primarily by the Hussite Wars at the beginning of the 15th century. Subsequent attempts to revive mining in the Jílové mining district were unsuccessful despite considerable investments. Approximately $97 \mathrm{~kg}$ of gold was produced during the entire 16th century. The situation in other mining districts was similar. Nový Knín and Libčice provided only $15 \mathrm{~kg}$ of gold, Kašperské Hory $51 \mathrm{~kg}$, and the Český Krumlov District $116 \mathrm{~kg}$. Historical documentation of gold production in other districts does not exist. The total production of Bohemian gold mines for this entire period is estimated at 48 tonnes of gold (Morávek ed. 1992).

\subsection{Preindustrial era (the 17 th century to the beginning of the 19 th century)}

At the onset of industrialization, the already classic gold localities in the present-day Czech Republic (Jílové u Prahy, Kašperské Hory, Zlaté Hory) were exhausted by earlier mining. The sole exception was the gold mine at Roudný near Vlašim. Mining at this locality, where Celts had likely already panned, has been documented at the end of the Middle Ages and at the end of the 18th century. In 1650, an attempt was made to revive the mines at Zlaté Hory, and approximately $107 \mathrm{~kg}$ of gold were produced from 1653-1714. In the 17th and 18th centuries, a total of 250-300 kg of gold were produced in the present-day Czech Republic (Kořan 1980). 


\subsection{Industrial era}

(1st half of the 19th century - 1st half of the 20th century)

In the 19th century, the annual gold production at Jílové and Kašperské Hory was approximately $20 \mathrm{~kg}$. A turning point during the 19 th and 20th centuries in gold mining in the present-day Czech Republic was the development of the Roudný gold mine. This followed the mining activities that were conducted earlier at this deposit and increased gold production considerably, up to $400 \mathrm{~kg}$ annually. Operations at the Roudný deposit recommenced in 1893, and production there totalled nearly $172 \mathrm{~kg}$ of gold from 1896-1901. A renewed interest in gold began during this period, leading to a renewed development of many historical mining districts. However, considerable success was achieved only at the Roudný deposit, where 664 thousand tonnes of run-of-mine ores were produced between 1904-1930, with grades of approximately $10 \mathrm{~g} / \mathrm{t}$ of gold, from which $5,770 \mathrm{~kg}$ of pure gold was obtained. The Roudný mine produced 200-250 kg of gold annually until 1930. At the turn of the 19th and 20th centuries, the Krásná Hora District also ranked as one of the important mining districts, producing nearly $400 \mathrm{~kg}$ of gold. Other districts included the Libčice mine, which operated until 1923. Its operation was revived shortly from 1941-1945. A total of approximately 6.9 tonnes of gold was produced in the Czech Republic region in the third era (Morávek 1980).

\subsection{Second half of the 20th century}

Attempts to revive gold mining continued with greater intensity after 1945 . However, mining resumed only in the Jílové mining district from 1958-1968, when a total of $1,133 \mathrm{~kg}$ of gold was produced. During this period, however, the Jílové deposit produced a total of approximately 1.5 tonnes of gold in ore with an average recovery ranging from $75-85 \%$. Due to the low metal content of the mined ore and the low gold price that had previously remained stable over a long period at $35 \mathrm{USD} /$ troy ounce of gold $(1.1 \mathrm{USD} / \mathrm{g})$, gold mining in the Jílové mining district was discontinued and the mine was abandoned (Morávek and Litochleb 2002).

Because of the sharp rise in the price of gold at the beginning of the 1970s, which in the 1980s exceeded the previous price by as much as twenty-fold (this price rise was connected to the unpegging of the American dollar (USD) from the gold standard), selected mining proceeded in 1989-1994 at the richest gold-bearing sections of the Zlaté Hory-West deposit. The total output of the deposit amounted to 1.6 tonnes of gold in ore and yielded 1.2 tonnes of gold (Zelinger ed. 1998). Select mining from 1986-1992 was also conducted at the gold-antimony ore deposit at Krásná Hora, producing nearly $420 \mathrm{~kg}$ of gold in ore and yielding $334 \mathrm{~kg}$ of gold. Small amounts of gold were also recovered from 1989-1992 while extracting polymetallic ore at the Zlaté Hory-East deposit and during a trial extraction from 1989-1990 at the Prostřední Lhota-Čelina deposit. The total gold production in the Czech Republic in the 
20th century reached nearly 9 tonnes, of which approximately 3 tonnes were produced after World War II (Morávek ed. 1992).

\section{Trend in gold reserves in the Czech Republic from 1945 to the present}

From the period after World War II until the mid-1960s, the total registered geological resources of gold in the CR were concentrated in the Jílové and Krásná Hora mining districts. Their volume ranged between 2.5 to 4.5 tonnes of gold depending on the status of exploration. However, in 1966, they more than doubled due to a recalculation of resources in the Zlaté Hory mining district. After 1968, the geological resources of gold increased again slightly to nearly 19 tonnes. This was related to the termination of mining at the Jílové deposit, as well as their subsequent recalculation and reclassification as potentially economic resources.

After a decade without practically any changes, another increase in the geological resources of gold occurred in 1978, when they grew slightly to 21.5 tonnes in connection with resources recalculation at the Zlaté Hory deposit.

The last extensive exploration for gold deposits in the CR region was conducted at the end of the 1970s, which was due to the rise in gold prices in the 1970s. The theoretical foundations of this exploration were laid by the findings of the Assessment of the Prognosis for Gold in the Bohemian Massif (Morávek ed. 1985). The project estimated the total amount of prognosticated gold resources in the $\mathrm{CR}$ at 400 tonnes. The actual mineral exploration verified several deposits with significant resources of gold ore, and these deposits were then progressively included in the Register of Reserved Mineral Deposits of the Czech Republic (hereafter referred to as the "Register"). In 1980, the Voltýřov deposit with total geological resources of gold of approximately 4 tonnes was included, followed in 1982 by the Čelina-Psí Hory deposit with over 4 tonnes, which increased the total geological resources of gold in the CR to 32 tonnes. However, there was a large increase that began in 1985 when the Mokrsko deposit with resources exceeding 47 tonnes was included in the Register. Another significant increase occurred in 1990, when the Kašperské Hory deposit with more than 10 tonnes of gold was added to the Register. The following year, the Suchá Rudná deposit was included in the Register and the total registered geological resources of gold in the CR surpassed 100 tonnes. In 1992, the resources of the Mokrsko deposit were recalculated after the exploration phase was concluded. Due to the new calculation, the resources increased by 72 tonnes to a total of nearly 119 tonnes and, together with other small changes, the total geological resources of gold in the CR grew to 173 tonnes. In 1993, the exploration phase was concluded at the Kašperské Hory deposit, where the total resources rose to 55 tonnes. In 1995, the last new large deposit Vacíkov with 33 tonnes of gold was added to the Register, and the total resources of gold in the CR thus reached 249 tonnes. This concluded the exploration for gold in the $\mathrm{CR}$ and, in subsequent years, only a few existing deposits were 
revaluated. During the following decade, the total resources of gold in the CR were slightly reduced to 239 tonnes, which has remained unchanged since 2007 (Fig. 2).

At the present time, a total of 15 gold deposits are registered in the Czech Republic. However, these deposits have not been exploited and no gold has been produced from other deposits. In the deposits mentioned above, 48.740 tonnes of economically proven resources and 28.644 tonnes of economically inferred resources have been registered. In addition, 161.516 tonnes of potential economic resources have also been recorded. Thus, a total of 238.9 tonnes of gold resources have been calculated in 15 deposits in the Czech Republic. In addition to the gold resources already mentioned, 60.221 tonnes of prognosticated resources in the $\mathrm{P}_{1}$ category and 52.246 tonnes in the $\mathrm{P}_{2}$ category have also been calculated in the Czech Republic. Thus, a total of 112.467 tonnes of gold in the category of prognosticated resources have been recorded (Morávek ed. 1985; Starý et al. eds. 2013).

Today, there are 351.367 tonnes of gold recorded in the Czech Republic. This amount represents the sum of resources. Economically recoverable reserves have never been calculated from any of these resources, which would be supported by feasibility as well as Environmental Impact Assessment (EIA) studies. Czech experts assume that preparing these types of studies, based on presupposed economically recoverable reserves, would

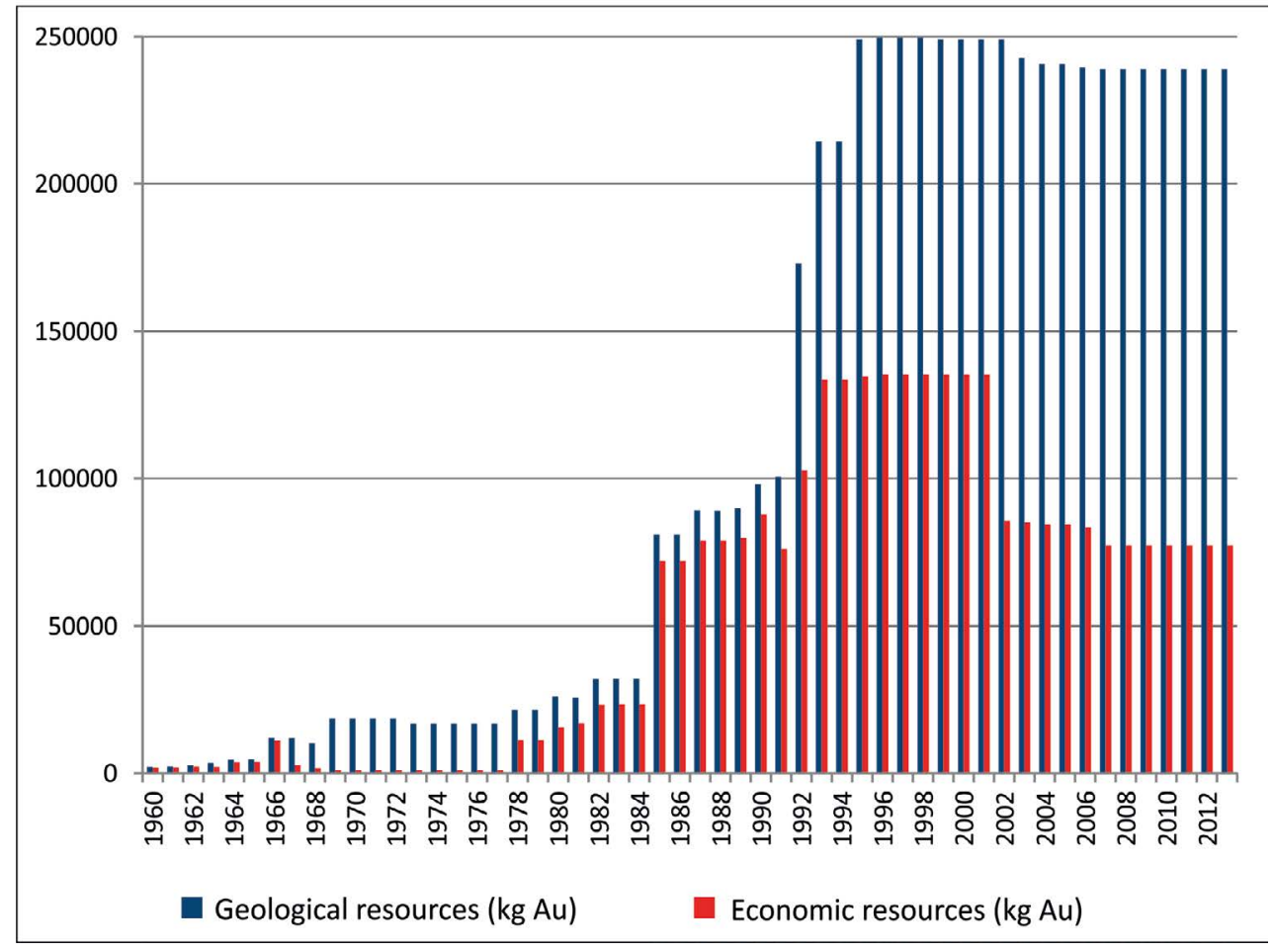

Fig. 2. Trends in gold resources in the Czech Republic region since 1960

Rys. 2. Trendy zasobów złota w Republice Czeskiej od 1960 roku 
require additional exploration so that the reserves of interesting deposits, from a mining technology perspective, could be upgraded to higher categories concerning their level of importance.

Currently, the most important gold deposits in the CR are Kašperské Hory, Mokrsko and Vacíkov. The resources of the first two deposits exceed 100 tonnes of gold (in the case of Kašperské Hory including prognosticated resources) and thus rank in the "world class" category.

\section{Gold production in the Czech Republic and EU countries and their rank in world statistics}

In the 1980s and 1990s, with the exception of uranium ore, the Czech Republic phased out ore mining, which as a whole was highly unprofitable and did not allow for the economic mining of deposits in a market-based economy. The last gold produced in the Czech Republic was produced in March 1994 (75 kg were produced from January to March) in Zlaté Hory, as the last amounts of ore were processed during liquidation work at this deposit. The actual active mining operations at this deposit (the last to be mined in the CR) were already terminated in $1993(512 \mathrm{~kg})$. Gold production achieved in the CR from 1958 until the end of mining is shown in Figure 3. The data indicate that production fluctuated between approximately 100 to $200 \mathrm{~kg}$ of gold annually during the last period. The rise in mining

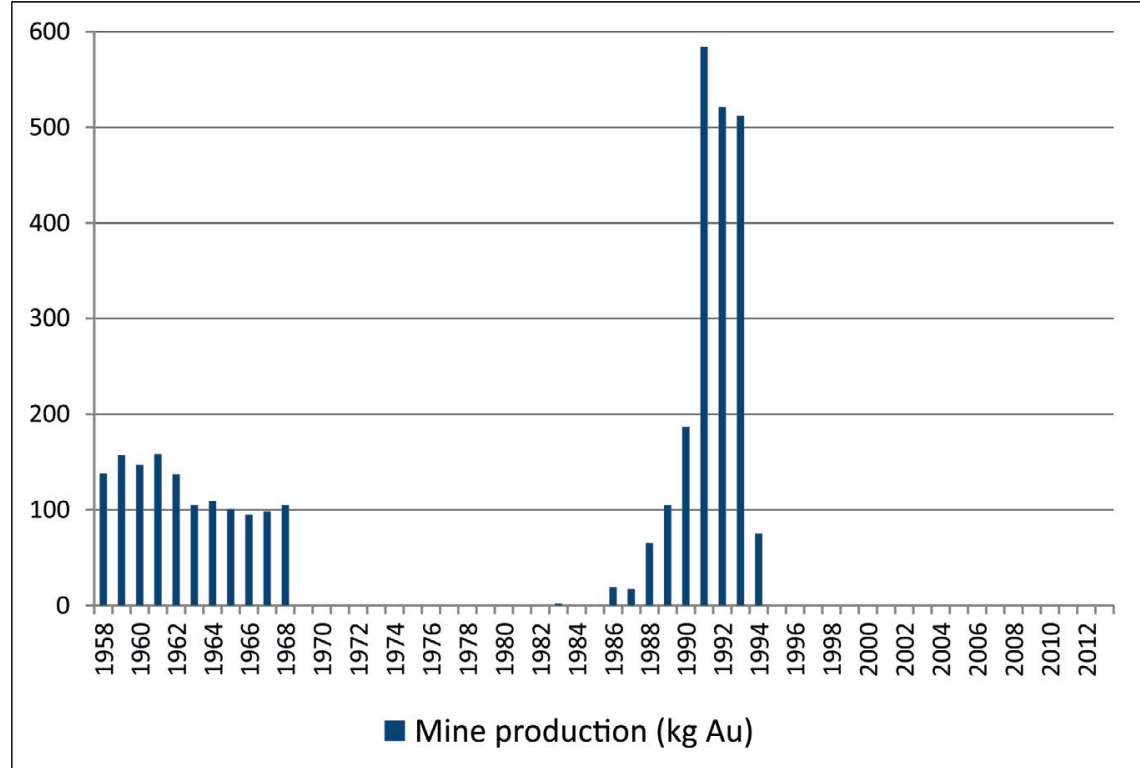

Fig. 3. Development of gold mine production in the CR since 1958

Rys. 3. Rozwój produkcji złota w Republice Czeskiej od 1958 roku 
output during the last years of the monitored period (1990-1993) was the result of a final extraction of the Zlaté Hory deposit in connection with the end of mining at this deposit.

Currently, gold is mined in eight member states of the European Union (Brown et al. 2013). These are (alphabetically) Bulgaria, Finland, Poland, Romania, Serbia, Slovakia, Sweden and the United Kingdom, which collectively produced 21.070 tonnes of gold in 2011 (Fig. 4). Of the European countries outside the European Union, Turkey registered an output of 23.248 tonnes in 2011, which is a higher total than the combined production of the member states of the European Union. The data on various measures are not entirely consistent. For example, in addition to the gold producers mentioned above, the USGS also lists other countries in which gold was supposedly produced in 2011. These include Denmark (153 kg), France (1 $500 \mathrm{~kg})$, Italy (450 kg), Greece (600 kg) and Spain (3 $500 \mathrm{~kg})$. Slight differences in various statistics concerning the output of individual countries exist as well.

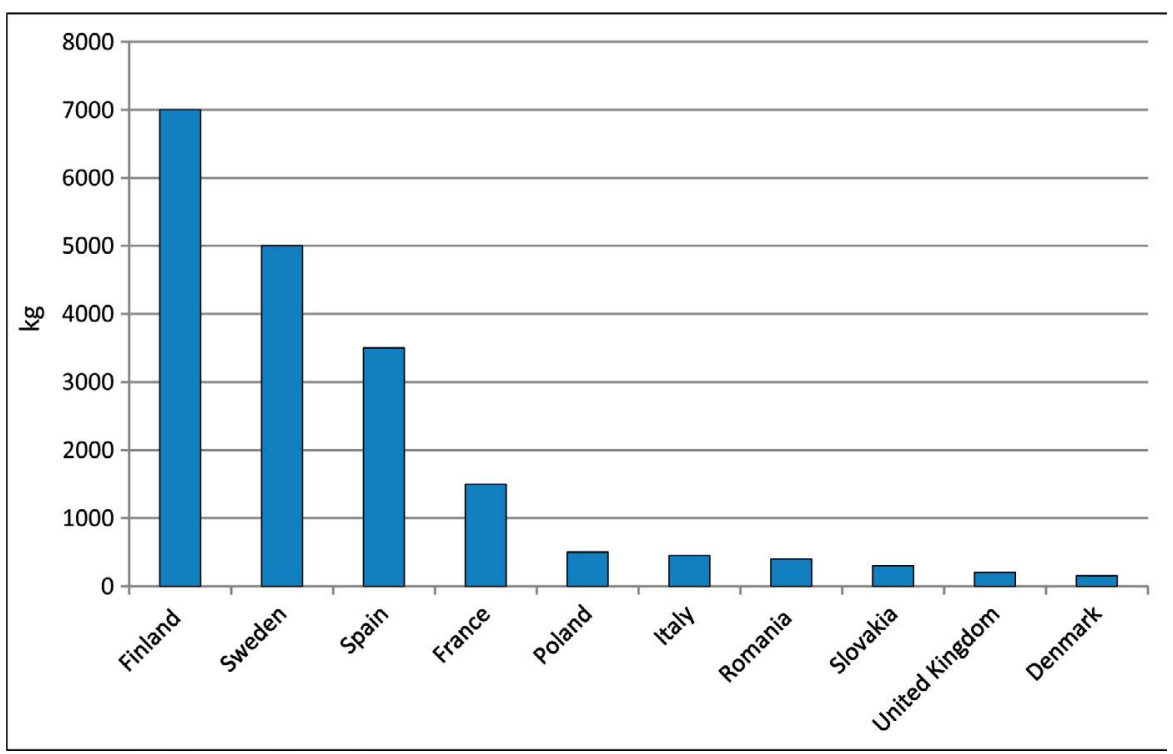

Fig. 4. EU countries mining gold deposits in 2011 - mine production (George 2013)

Rys. 4. Kraje UE eksploatujące złoża złota w 2011 roku - produkcja górnicza (George 2013)

If gold production from deposits is taken into account, statistics from the USGS (George 2013) list the output in 2011 at 2660 tonnes (estimated), of which nearly 1800 tonnes of gold (precisely 1763 tonnes) were produced by the top ten producers (Fig. 5). These do not include any country in the European Union. In 2011, 101 countries produced gold. Finland, which recorded the highest output ( 7 tonnes) in 2011 of all countries in the European Union, ranked 37 th.

It cannot be expected that future gold production in the CR would place the CR among the top producers. Forecasts estimate that annual production may hover at approximately 4 tonnes to cover domestic gold consumption, which is estimated at approximately 5 tonnes 


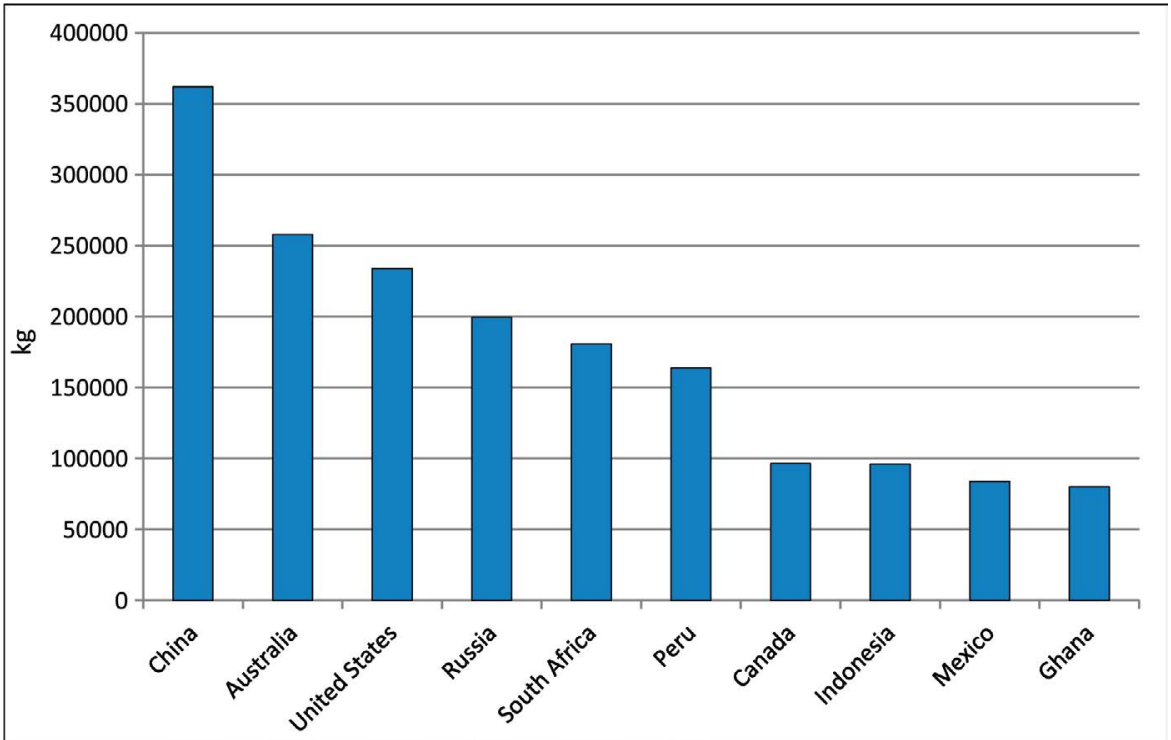

Fig. 5. World gold production in 2011, and the top ten producers and their mine production in 2011 (George 2013)

Rys. 5. Światowa produkcja złota w 2011 roku, dziesięć największych producentów i ich produkcja w 2011 roku (George 2013)

(Morávek 2011). It would, however, be an interesting amount as far as gold production in the European Union as well as in Europe alone is concerned.

\section{Gold exploration, mining and processing in the Czech Republic from a legislative and mineral policy perspective}

Even though interesting deposits of gold and gold-tungsten ores on a European scale occur in the Czech Republic, they are currently neither exploited nor explored. Surveys of promising gold-bearing deposits remained unfinished and therefore mining projects cannot be planned. Technological surveys have also not been completed and required studies have not been prepared (primarily Environmental Impact Assessment - EIA). In the last decade, exploration for gold ores has been discontinued and new exploration projects are not being permitted by environmental agencies. This also corresponds to the legal opinion of the Czech Republic's Ministry of the Environment and of the minister's appointed committee, which states that the right to grant an exploration permit does not exist, according to $\S 4$ a par. 6 of Act No. 62/1988 Coll., on Geological Projects, as amended (GP 1988).

The change in political and therefore economic conditions at the end of the 1980s led to the end of state-funded mineral exploration. For this reason, the Ministry of Trade of the 
Czech Republic put out a tender in 1994 with the aim of providing funding for exploration by private companies. However, the winning companies were not able to complete the exploration due to opposition from concerned municipalities, citizens and ecological associations. Then, at the end of the 1990s, with its Resolution No. 516 on 26 May 1999 (Resolution CR 1999), the government of the Czech Republic took a negative stance on further exploration as well as gold mining in the country.

The long-term exploitation of the domestic mineral resource base, together with the issues mentioned in the paper, are the reasons why the Czech Republic is completely dependent on the import of all ores and metals, with the exception of uranium ore, and why ores are not produced domestically. The entire domestic metal consumption is from imports. Furthermore, this fact does not correspond to the official policy of the European Union, which currently stresses the use of domestic mineral resources to ensure the mineral security of countries (Communication EC 2011).

The problem of gold ore processing became a separate issue when the European Parliament adopted Resolution No. P7_TA(2010)0145 on 5 May 2010, which was a general ban on the use of cyanide mining technologies in the European Union (Official Journal of the European Union 2011/C 81 E/13) (Resolution EP 2010). The government of the Czech Republic had already taken a negative stance on the use of cyanide leaching. The amendment of the Mining Act (GP 2000) bans the use of cyanide leaching technology or other procedures using cyanide compounds, specifically on any scale as well as the separate use of cyanide leaching in combination with other methods of mineral processing and beneficiation. This legislation was a reaction to an environmental disaster in a Romanian gold mine near Baia Mare in 2000, when a dam holding water contaminated with cyanide and heavy metals burst and contaminated sections of the Tisza and Danube Rivers (Soldán et al. 2001). The amendment banned the use of cyanide in mineral extraction, although cyanide was generally not used in the mining industry at that time. This ban basically prevents the use of the only effective methods of processing gold-bearing ores in the case of low-grade deposits. Currently, the Czech mining act basically prevents the exploitation of registered deposits of gold ore in the Czech Republic, and thereby influences the exploration of gold deposits as well.

In the Czech Republic, it is therefore possible to process gold-bearing ores only with the use of gravity concentration, flotation, refining, electrolytic refining, and also with new but economically demanding methods, such as ore leaching with thiourea solutions (La Broy et al. 1994; Aylmore nad Muir 2001; Grosse et al. 2003). In theory, it would also be possible to process gold-bearing ores using the old amalgamation process, which is environmentally unacceptable as well and rarely used on an industrial scale (Hinton et al. 2003; Veiga et al. 2006). Furthermore, it would contradict the European mercury elimination strategy (Communication EC 2010).

The problem of cyanide leaching is of course not only a current issue in the Czech Republic; it has wider ramifications and is closely connected to environmental protection. The exceptional incident connected with the release of cyanide from the Romanian mine Aural in Baia Mare in January 2000 was the catalyst for developing "The International Cyanide 
Management Code For The Manufacture, Transport and Use of Cyanide in the Production of Gold“ - Cyanide Code (UNEP \& ICME). Early in 2002, the organizing committee completed the Cyanide Code, which lists international cyanide regulations of verified procedures for cyanide use in mineral processing, manufacture and transport. The Cyanide Code currently states that the process of cyanide use and its implementation must be verified by an independent auditor. Thereafter, the findings on cyanide use must be transparent and made available to the public. The International Cyanide Management Institute (ICMI) was then founded in 2003.

The Czech Republic has an approved mineral policy from 1999 (MIT CR 1999). Last year, an updated version of the mineral policy was prepared and has not yet been approved (MIT CR 2012). Of all ores, gold is the only mineral that is singled out and evaluated in the updated version of the Mineral Policy of the Czech Republic from 2012. The most important deposits mentioned in the text are Kašperské Hory and Vacíkov, Mokrsko-East, as well as, among the smaller deposits, Čelina and Voltýřov. The economic importance of the Kašperské Hory deposit is also reinforced by the presence of tungsten ore with an average content of $1.3 \%$ of tungsten and approximately 42 thousand tonnes of potential economic resources. With regard to the current status of registered gold resources in the Czech Republic, the mineral policy proposal states that the mineral exploration was not completed in the past and that the knowledge regarding resources is currently not at a level that would allow for the required mining and economic studies to be prepared. EIA studies have also not been prepared. The text further mentions "that in the case of a positive stance of state authorities, it would be possible to find acceptable solutions to the conflicts of interest involving environmental protection agencies and local administrations, which would provide considerable tax revenues for the country as well as regions and, in the case of the state's participation, even a share of investment income, which is standard practice in other countries. The objectives and measures of the prepared proposal of the updated mineral policy of the Czech Republic (MIT CR 2012) also indirectly involve gold deposits in some regards, although it is clear that the primary interest regarding exploration and ore deposit mining is on uranium ore. Of the main objectives of the proposal in the updated version of the mineral policy of the Czech Republic (MIT CR 2012), gold deposits are predominantly affected by the objective "Reevaluating the Real Potential of Ore Deposits under Current Economic Conditions" and by the objective "Improving the Public Perception of the Mining Industry." However, a link to the acquisition of gold deposits can also potentially be found in the wording of the other main objectives in the document. The proposal in the updated version of the mineral policy of the Czech Republic (MIT CR 2012) also defines specific tasks of the mineral policy. Of these, gold deposits are mostly affected by task no. 11: "Reevaluating the status of resources of selected ore deposits according to current exploitation conditions for state administration decisions regarding local territories and for assessing the economic profitability of their eventual future exploitation.” 


\section{Conclusion}

The Czech Republic, at least from a European perspective, has interesting deposits of gold. As our analysis shows, the exploitation of these deposits is restricted primarily due to concerns regarding the environmental impacts of mining and processing of extracted minerals. It seems that a key aspect is mainly the existing ban on the use of cyanide mining technologies in the Czech Republic. A new and yet-to-be-approved proposal of the updated version of the mineral policy of the Czech Republic (MIT CR 2012) is attempting to gradually change this stance. However, we assume that this will be a long and complex process because the main problem still lies in the unfinished surveys of mineral deposits, which would specify the total amount of gold and upgrade the resources to higher categories concerning the level of exploration. Without these, it is impossible to prepare the necessary economic assessments of potential production and of the deposits to the fullest extent involving exploration, mineral extraction and processing, including subsequent reclamation of effected areas, elimination of mining impacts and regeneration of post-mining landscapes. Naturally, the findings of these analyses and thus the future of gold deposits in the Czech Republic depend greatly on future trends in the price of gold and possibly the accompanying (by-product) minerals found in gold deposits as well.

\section{Acknowledgements}

This study was made possible by the financial support from grant project no. SP2014/40 financed by the Ministry of Education, Youth and Sports of the Czech Republic. A detailed review by two anonymous reviewers improved our manuscript considerably

\section{REFERENCES}

Aylmore, M.G. and Muir, D.M. 2001. Thiosulfate leaching of gold - A review. Minerals Engineering 14(2), pp. $135-174$.

Brown et al. 2013 - Brown, T.J., Hobbs, S.F., Mills, A.J., Petavratzi, E., Raycraft, E.R., Shaw, R.A. and Bide, T. 2013. European mineral statistics 2007-11, Keyworth, Nottingham: British Geological Survey, 345 pp.

Cháb, J. ed. 2010. Outline of the geology of the Bohemian Massif: the basement rocks and their carboniferous and permian cover. Prague: Czech Geological Survey, 295 pp.

Communication EC 2010. Communication from the Commission to the European Parliament and the Council on the Review of the community strategy concerning mercury, $\operatorname{COM}(2010) 723$, Brussels. Available at: http://eur-lex.europa.eu/legal-content/EN/TXT/PDF/?uri=CELEX:52010DC0723\&from=EN

Communication EC 2011. Communication from the Commission to the European Parliament, the Council, the European Economic and Social Committee and the Committee of the Regions: Tackling the challenges in commodity markets and on raw materials, $\operatorname{COM}(2011) 25$, Brussels. Available at: http://eurlex.europa.eu/LexUriServ/LexUriServ.do?uri=COM:2011:0025:FIN:EN:PDF.

George, M.W. 2013. Gold. [In:] 2011 Minerals yearbook [Online]. USGS, pp. 31.1-31.23. Available at: http://minerals.usgs.gov/minerals/pubs/commodity/gold/myb1-2011-gold.pdf [Accessed: 8 April 2014]

GP 1988. Act No. 62/1988 Coll., on Geological projects, as amended (in Czech).

GP 2000. Act No. 366/2000 Coll., the Amendment of the Act on geological projects and the Mining act (in Czech). 
Grosse et al. 2003 - Grosse, A.C., Dicinoski, G.W., Shaw, M.J. and Haddad, P.R. 2003. Leaching and recovery of gold using ammoniacal thiosulfate leach liquors (A review). Hydrometallurgy 69(1-3), pp. 1-21.

Hinton et al. 2003 - Hinton, J.J., Veiga, M.M. and Veiga, A.T.C. 2003. Clean artisanal gold mining: A utopian approach? Journal of Cleaner Production 11(2), pp. 99-115.

Kořan, J. 1980. Mine gold production in the history of Bohemian lands. Rozpravy Národního Technického Muzea v Praze, Studie z Déjin Hornictvi 12, pp. 47-74 (in Czech with German summary).

La Broy et al. 1994 - La Broy, S.R., Linge, H.G. and Walker, G.S. 1994. Review of gold extraction from ores. Minerals Engineering 7(10), pp. 1213-1241.

MIT CR 1999. Mineral policy for raw materials and their resources (approved by the Government of the Czech Republic Resolution No. 1311 of 13 December 1999). Ministry of Industry and Trade of the Czech Republic (MIT CR) (in Czech).

MIT CR 2012. Proposal of the Mineral Policy of the Czech Republic. Prague: Ministry of Industry and Trade of the Czech Republic (MIT CR) (in Czech).

Morávek, P. 1980. Gold production in the history of Bohemian lands. Rozpravy Národního Technického Muzea v Praze, Studie z Déjin Hornictvi 12, pp. 75-92 (in Czech with German summary).

Morávek, P. 2011. Gold yesterday, today and tomorrow. Minerálni Suroviny 4, pp. 20-23 (in Czech).

Morávek, P. ed. 1985. Assessment of the gold prognoses of the Bohamian Massif, Final Report. Praha: Geoindustria (in Czech).

Morávek, P. ed. 1992. Gold in the Bohemian Massif. Praha: Český Geologický Ústav, 248 pp. (in Czech with English summary).

Morávek, P. and Litochleb, J. 2002. The Jilové gold mines. Jílové u Prahy: Regionální Muzeum, 187 pp. (in Czech with English and German resume).

Resolution CR 1999. Government of the Czech Republic Resolution No. 516 of 26 May 1999, on Prospection and extraction of gold in the territory of the Czech Republic (in Czech).

Resolution EP 2010. European Parliament, Resolution of 5 May 2010 on a General ban on the use of cyanide mining technologies in the European Union, P7 TA(2010)0145, Brussels. Available at: http://www.europarl.europa. eu/sides/getDoc.do?pubRef=-//EP//TEXT+TA+P7-TA-2010-0145+0+DOC+XML+V0//EN.

Soldán, P., Pavonič, M., Bouček, J. and Kokeš, J. 2001. Baia Mare accident - Brief ecotoxicological report of Czech experts. Ecotoxicology and Environmental Safety 49(3), pp. 255-261.

Starý et al. 2013 - Starý, J., Sitenský, I., Mašek, D., Hodková, T., Kavina, P. eds. 2013. Mineral commodity summaries of the Czech republic 2013: Statistical data to 2012. Prague: Czech Geological Survey, $311 \mathrm{pp}$.

UNEP \& ICME. International Cyanide Management Code for the Manufacture, Transport and Use of Cyanide in the Production of Gold (Cyanide Code). [Online] United Nations Environmental Program \& International Council on Metals and the Environment (UNEP \& ICME). Available at: http://www.cyanidecode.org [Accessed: 8 April 2014].

Veiga et al. 2006 - Veiga, M.M., Maxson, P.A. and Hylander, L.D. 2006. Origin and consumption of mercury in a small-scale gold mining. Journal of Cleaner Production 14(3-4), pp. 436-447.

Zelinger, O. ed. 1998. Jeseník Ore Mines, state enterprise, in period 1958-1998. Jeseník: RD Jeseník, 216 pp. (in Czech). 
ZLOŻA ZLOTA W REPUBLICE CZESKIEJ

Z PUNKTU WIDZENIA POLITYKI SUROWCÓW MINERALNYCH

Słowa kluczowe

złoto, czeski masyw, polityka surowców mineralnych, ługowanie cyjankiem

\section{Streszczenie}

Produkcja złota w Czechach ma ponad tysiącletnią tradycję sięgającą trzeciego wieku przed naszą erą. Ogółem do końca 1994 roku wyprodukowano około 100 ton złota, z czego prawie 9 ton zostało wyprodukowanych w XX wieku i około 3 tony - po II wojnie światowej. Znaczne złoża złota odkryto podczas ostatnich rozległych badań, przeprowadzonych w latach 1970-1995, które determinowane były gwałtownym wzrostem cen złota w latach 1970-1980. Odkryto 15 złóż złota o zasobach geologicznych wynoszących 239 ton. Kolejnych 112 ton złota oszacowano w zasobach prognostycznych. Żadne z tych złóż nie jest eksploatowane z powodu nierozwiązanych problemów dotyczących ochrony środowiska. Eksploatacja tych złóż jest ograniczana przede wszystkim ze względu na obawy dotyczące wpływu na środowisko procesów wydobywczych i przetwórstwa wydobywanych kopalin. Kluczowym aspektem tych ograniczeń jest istniejący zakaz stosowania technologii wydobywczych z wykorzystaniem cyjanku. Nowy, jeszcze nie zatwierdzony, wniosek o zaktualizowanej polityce surowców mineralnych w Czechach, stopniowo stara się zmienić tę postawę. Jeszcze innym problemem są niedokończone badania złóż kopalin, które określą całkowitą ilość złota i spowodują przeszacowanie zasobów do wyższych kategorii. Bez nich niemożliwe jest przygotowanie niezbędnych analiz ekonomicznych, potencjalnej produkcji, rekultywacji obszarów dotkniętych działalnością górniczą. Przyszłość złóż złota w Republice Czeskiej zależy również od przyszłych trendów cen tego surowca i towarzyszących mu (produkt uboczny) minerałów.

\section{GOLD DEPOSITS OF THE CZECH REPUBLIC FROM A MINERAL POLICY PERSPECTIVE}

\section{Keywords}

gold, Bohemian Massif, mineral policy, cyanide leaching

\section{Abstract}

Gold production in the region that currently makes up the Czech Republic has a thousand-year-old tradition with peaks around the third century BC, $14^{\text {th }}$ century AD and $20^{\text {th }}$ century AD. In general, approximately 100 metric tonnes were produced by the end of mining in 1994, of which nearly 9 tonnes were produced in the 20th century and approximately 3 tonnes were produced after World War II. Significant gold deposits were discovered during the last extensive exploration conducted in the 1970s to 1995 , motivated by the sharp rise in the price of gold at the beginning of the $1970 \mathrm{~s}$ and in the $1980 \mathrm{~s}$. Fifteen deposits with 239 tonnes of geological resources of gold were registered. Another 112 tonnes 
are recorded as prognosticated resources. None of these deposits are mined, due to unresolved issues involving environmental protection. The exploitation of these deposits is restricted primarily due to concerns regarding the environmental impacts of the mining and processing of extracted minerals. A key aspect of these restrictions is likely the existing ban on the use of cyanide mining technologies. A new and yet-to-be-approved proposal for an updated mineral policy in the Czech Republic is attempting to gradually change this stance. Yet another problem lies in the unfinished surveys of mineral deposits, which would specify the total amount of gold and upgrade the resources to higher categories concerning the level of exploration. Without these, it is impossible to prepare the necessary economic assessments of potential production and of the deposits to the fullest extent of activities involving exploration, mineral extraction and processing, including subsequent reclamation of affected areas, elimination of mining impacts and regeneration of post-mining landscapes. The future of gold deposits in the Czech Republic also greatly depends on future trends in the price of gold and accompanying (by-product) minerals occurring together with gold in mined ores. 
